\title{
11
}

\section{Three-Dimensionality Rather than One-Dimensionality}

The bottom line is becoming three-dimensional. To achieve such results, the entire organization must be designed in a way that renders the company able to

become sustainable and profitable. This requires setting the right objectives socially, environmentally and financially; it requires measuring and monitoring the right things and communicating them to those who need the information. Not at least, it requires rewarding individuals, groups and entities who are able to help the company become more sustainable. In such a way, the company can be designed to pull powerfully and consistently in the right direction.

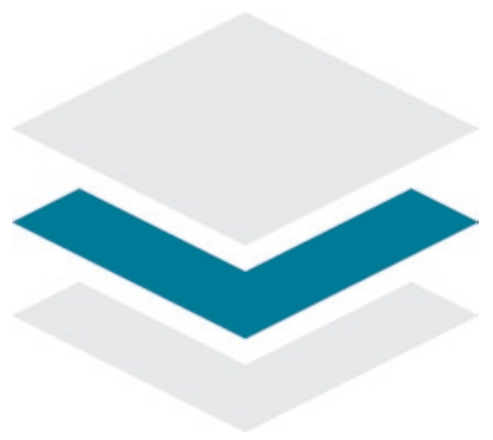

Fig. 11.1 Three-dimensionality Rather than One-dimensionality

(C) The Author(s) 2018

S. Jørgensen, L. J. T. Pedersen, RESTART Sustainable Business Model Innovation, Palgrave Studies in Sustainable Business In Association with Future Earth, https://doi.org/10.1007/978-3-319-91971-3_11 


\subsection{Take the Lead}

Could you imagine dying on Mars? Elon Musk, the CEO of Tesla and SpaceX, has stated that he would like to do so. He has also said that if something is important enough to die for, you should pursue it. And with his recent high-profile effort to send a car spiraling into space, with a sign that says "Don't panic!" and David Bowie's "Space Oddity" playing on an endless loop on the stereo, Musk indeed appears to be successfully exploring space (Fig. 11.1).

A group of engineers founded Tesla in Silicon Valley in 2003 to prove that electric vehicles could outperform cars with combustion engines. The company has since revolutionized the automotive industry with its electric vehicles and has already innovated its business model so comprehensively that it has become something more than an ordinary car manufacturer.

Tesla produces and sells more and more cars, and it develops new models-most recently, it has made public its intention to produce a Tesla truck. The company's objective is to make cars gradually cheaper, so that Tesla in turn can realize its vision: to accelerate the world's transition to sustainable transportation. One of Musk's many ideas is the concept he calls the hyperloop. The hyperloop is comparable to a pneumatic tube, and supposedly allows for people being transported in velocity up to $1220 \mathrm{~km} / \mathrm{h}$. Musk and the engineers in one of his companies prepared and described this concept in a 57-page design document, which they distribute freely to anyone who is interested. Hyperloop Technologies is now working to realize the project, and it hopes to commercialize the concept around 2020.

Musk, who was also one of the founders of PayPal, started work on the project SpaceX already at the turn of the century. SpaceX develops, manufactures, sells and launches aerospace equipment. The company aims to enable people to live on other planets-hence Musk's desire to live (and die) on Mars. Musk is also one of the founders of the rapidly growing company SolarCity-the second largest supplier of solar power in the United States. Musk has revealed that he plans to integrate the business models of Tesla and SolarCity in order to tie together 
the companies' mobility services and energy solutions. Importantly, however, Musk must ensure the economic viability of his various ventures, as at the time of writing, many analysts ponder whether Tesla will indeed be able to survive financially.

Like many other prominent CEOs, Musk is also chairman of a foundation. The Musk Foundation aims to spread solar power to disaster areas. In addition, he serves in various roles for numerous other companies that deal with mobility, energy and innovation. In these ways, Musk has taken a leadership role in the shift toward a greener future-both by virtue of his formal roles and as a global thought leader. Thus, he contributes to creating awareness about problems as well as potential solutions, and he takes part in creating a perception that the solutions are realistic. This leadership role-which both Musk and other executives occupy both within and outside their own companies-is a key to making change happen.

There is no doubt that Elon Musk has financial ambitions for Tesla and SpaceX and that he is concerned about both growth and market share. At the same time, he communicates clearly that the social and environmental dimensions of all his projects are important. He is apparently successful at mobilizing employees at all levels to pull in the same direction toward ever more ambitious solutions for a more sustainable world. Research on companies that manage to combine sustainability and profitability suggests that commitment and anchoring of sustainability efforts at the highest level of the organization are critical to the success of mobilizing and motivating employees to comply with the sustainability vision (Eccles et al. 2014). It is not enough to have a triple bottom line that emphasizes financial, social and environmental performance (Elkington 1997). It must also be communicated to employees in a way that makes it credible, relevant and able to stimulate contribution from employees (Du et al. 2010; Strand 2013, 2014). This further requires designing the organization in a manner that supports these objectives with regard to organizational design and management control systems (Gond et al. 2012; Schaltegger 2011; Gulbrandsen et al. 2015). To succeed with truly three-dimensional performance, leadership and organizational design must facilitate it. 


\section{Take Me to Your Leader}

In his book The Innovator's DNA, Harvard Business School professor Clayton Christensen (2013) asks what characterizes leaders who drive innovation. He concluded that leaders and their characteristics are of crucial importance for the ability of companies to innovate. Leadership involves creating support for the managers' and organization's objectives. Managers can, for instance, do this by making work meaningful to employees. Workers are not necessarily bound to obey orders or blindly let themselves be led by formal frameworks. This implies that voluntary action is an important, but often overlooked, concept related to leadership. In most cases, managers have power that could enable them to steer employees in a desired direction. However, management is not just about controlling, but rather, both the ability to lead and the ability to control are essential tools in a manager's toolbox.

Since both employees and other stakeholders have the freedom to choose, managers can only control these stakeholders' actions to a limited extent. This is particularly true in cases where the company breaks with its previous practices, such as when it tries to develop a more sustainable business model. A key challenge for managers is directing employees' attention toward performance along all three dimensions on which the company is measured.

Put simply, we can therefore say that good managers manage to stimulate collaboration by making targets meaningful (see, e.g., Shamir et al. 1993), but they also manage to control their employees through the formal structure of the organization. Working to improve sustainability performance can be perceived as meaningful for employees because of the characteristics of the objectives and the tasks involved in achieving them. For example, employees may find it rewarding or stimulating to work with new technologies to reduce emissions or with procedures that improve conditions for employees in the company's supply chain. However, to work toward such goals can also be experienced as meaningful if the target itself-that is, the vision that employees share and strive toward—has value for the individual employee (cf. Deci and Ryan 2000). 
To work in a company like Tesla and SolarCity can thus provide employees with rewarding sustainability-related work. Meanwhile, employees can also find these companies' visions to contribute to a more sustainable future valuable and motivating. It is important to emphasize that the organization's objectives, vision and values refer to a desired future state that everyone in the company must be willing to work together to achieve. Leadership thus involves setting the course and trying to create support for the goals and to stimulate cooperation among employees and other important stakeholders to attain them.

\section{Leadership at All Levels}

The tales of visionary and dynamic leadership personalities like Elon Musk and Ray Anderson of Interface can perhaps make it easy to lose heart. Most managers may not have either the capabilities or the resources needed to be large-scale change-makers, and many people lack such aspirations. It is therefore important to remind ourselves of the many everyday heroes we meet. A good example is the head of a technical department in a municipality. He set new goals for his unit, inspired his employees, their administrative head and the political decision makers in the municipality to implement new and more sustainable fuel alternatives both in public transport and in the municipality's own fleet of vehicles. This is not a sustainable business model innovation, but rather a change in the way the municipality deliver its services. It should be noted that it is a major change for the municipality, however, and it requires many stakeholders with different interests and goals to work together to attain new sustainability goals.

We come across plenty of other examples: Chief sustainability officers who succeed in changing the purchasing policy in large companies. HR managers who significantly improve the health, safety and environment (HSE) practices of their company. Product designers who redesign products so that they become more resource efficient and 
environmentally beneficial. Managers of marketing departments who join forces with chief financial officers (CFOs) to find new ways of offering existing products in markets that have not previously had access to such products. We have filled our backpack of experiences of sustainable business through numerous conversations with managers in small and large organizations across the private, public and voluntary sectors. It is interesting and inspiring to see how minor changes, often initiated from the grassroots of the organization, can also lead to significant subsequent changes in the direction of the organization becoming more sustainable. The reason is perhaps precisely that when a change is made to the way value is created, delivered or captured in the organization, it also spills over to other parts of its business model and operations.

It is therefore misleading to talk about leadership as something that only happens from the top of the organization. Developing sustainable business models is a result of leadership at different levels in the company, and it is a result of stakeholders with different expertise and experience questioning the existing practice. Often it is necessary that leaders and stakeholders inside and outside the company jointly work to set a new course.

The leaders who succeed in doing this must be able to formulate new visions, goals and values and manage to create movement in the new direction. They succeed with this not only by being a "guiding light" that shows the way. Reaching new targets also requires designing the organization in a manner that supports this, especially with regard to management control systems and other key characteristics of organizational design that encourages and supports performance along all three performance dimensions. Elon Musk and the companies in which he is involved have not been success stories solely because of visionary leadership. To realize the ambitious projects they have initiated, Tesla, SpaceX and SolarCity are completely reliant on formal systems and structures to create movement. Their success is also a consequence of appropriate management control and organization, which facilitates the alignment of sustainability and profitability. 


\subsection{Building a Better World}

LEGO has taught us that by using the right building blocks in the right ways, one can create anything. And it may appear that decision makers in the company have realized that this also applies to companies trying to become more sustainable.

In 2015, LEGO took a huge leap in that direction, when it announced that it would invest one billion Danish kroner to find sustainable materials for its products. To achieve this, the company has established a new unit - the Sustainable Materials Center, in which 100 people will work to replace the petroleum-based plastic that the company now uses to produce its world-famous LEGO blocks, with more environmentally friendly plastic. According to LEGO's CEO Jørgen Vig Knud Torp, this is an important step to attain the company's ambitions of using only sustainable materials by 2030. In 2018, LEGO announced that it would launch its first sustainable bricks, as all botanical elements such as leaves, bushes and trees in LEGO's collections will be made from plant-based plastic sourced from sugarcane, starting in 2018. Later on, these materials will also be used in other LEGO products.

These changes add to the company's existing sustainability performance, which includes a reduction in its carbon footprint, reductions in the size of the product packaging, as well as investments in the company's own wind power park. In 2014, LEGO also decided to exit its partnership agreement with Shell, which had lasted since the 1960s. This happened after a lengthy campaign Greenpeace had run against Shell. As such, the decision to change the input factors in the LEGO blocks is just a part of larger ongoing changes of the entire LEGO business model in a more sustainable direction. However, major challenges of course still remain-not at least related to consumption, waste and other shadowy sides of the major LEGO theme parks, which have expanded on several continents.

The new sustainable materials center will be located at LEGO's headquarters in Billund, Denmark, and will be represented at LEGO's various offices all over the world. According to the owner of the LEGO Group, Kjeld Kirk Kristiansen, the investment is part of the company's vision to 
create a positive footprint on the planet that future generations will inherit. It is also in line with the motto of his grandfather-LEGO founder Ole Kirk Kristiansen: "Only the best is good enough.” In 2014 alone, more than 60 billion LEGO blocks were produced, and the footprint thereof is massive. In 2012, the company therefore started work to find new solutions to reduce both its social and environmental externalities and started collaborating with partners including World Wildlife Fund (WWF) to find ways to become more sustainable. This includes collecting products at their end of life. In order to succeed, however, LEGO must ensure that appropriate organizational design and management control systems support the three-dimensional objectives in its vision. This is necessary to attain the ambitious goals the company has formulated as part of its strategy.

\section{Organizing for Sustainability}

Designing organizations in a way that reflects and supports the company's financial, social and environmental dimensions is a comprehensive challenge. However, it is important to mobilize and help employees at all levels contribute to make the company more sustainable. It is not sufficient merely to formulate goals along all three dimensions - the company must moreover be designed in a way that enables employees to act in accordance with those goals. Figure 11.2 illustrates four organizational characteristics that are particularly important for promoting simultaneous goal attainment along all three performance dimensions.

1. Assignment of authority and accountability within the organization and placement of suitable competence in the right places in the organization

2. Contact with stakeholders inside and outside the organization

3. Development and monitoring of control systems and performance indicators

4. Development of appropriate incentive structures 


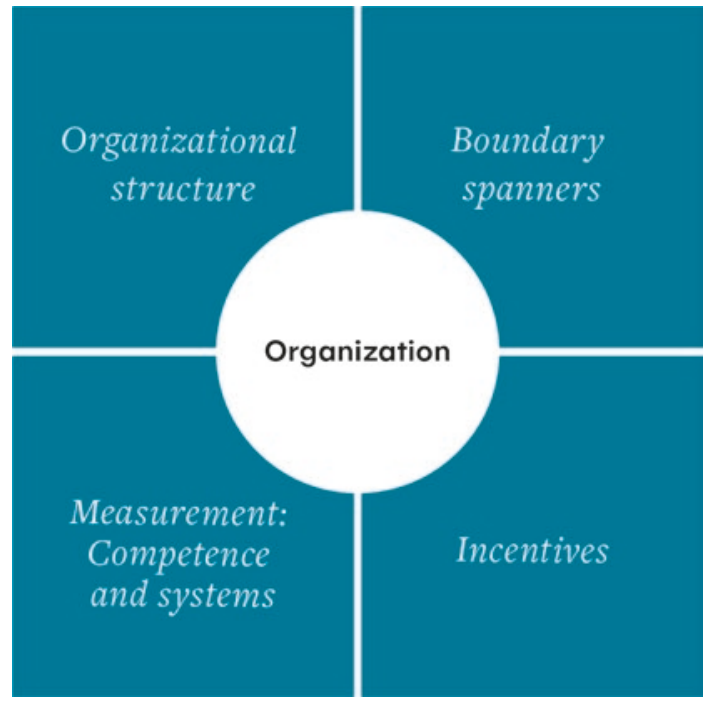

Fig. 11.2 Four elements of organizing for sustainability

\section{The Structures That Support}

To avoid reducing sustainability to a theme for celebratory speeches and a decoration on corporate websites and annual reports, it is important that those who are responsible for sustainability efforts gain real influence in the company. This is clearly the case in LEGO. The company formed a separate department with a solid budget and a dedicated manager who will be a part of the company's executive management.

One of the most important features of any organizational design is giving certain people the right to make decisions about resources in the company, as well as the corresponding accountability. These decision rights determine the opportunities they have to make independent choices and implement activities with the necessary resources (Foss et al. 2012).

LEGO's decision to create the new center places both authority and accountability to implement these changes with its managers. There is no doubt that these managers will deal with core business - they are after all 
redesigning the LEGO block! If LEGO is able to transition away from oil-based plastic, it may positively influence its reputation and strengthen its competitive advantage. However, it is not the public relations department that is tasked with these sustainability efforts, although LEGO's sustainability practices also relate to such aspects of the company. Instead, the sustainability center will be located in the heart of the company's activities. In this way, the project is built into the core of the organization, making it more likely that those who work there can take the necessary steps to improve the company's sustainability performance.

\section{Build a Bridge to Your Surroundings}

No company is an island. To the contrary, every organization depends on numerous stakeholders in its environment, which contribute to the organization attaining its objectives. The so-called boundary spanners play a key role in this (Aldrich and Herker 1977). Boundary spanners operate in the critical area where the organization "flows into" surroundings. Boundary spanners communicate with stakeholders but can also drive innovation projects that include individuals, groups or entities outside the walls of the organization. For instance, LEGO engages its customers in innovation activities, wherein they are encouraged to give suggestions for new products and product lines.

The boundary spanner has two primary roles. The first is to collect and process information that the company can benefit from in its decisions. The second is to represent the company in the external environment, for example, by carrying out stakeholder dialogue or building legitimacy among stakeholders. This work supports the company's risk management and contributes to knowledge gathering that can be valuable for business development and innovation (Aldrich and Herker 1977; Seuring and Gold 2013).

Being in touch with stakeholders in this way has an accountability side ("who are affected by the company's activities, and what does that mean for the company?") and an opportunity side ("who is able to influence the company's activities, and what does that imply for the company?"). Through its open innovation work, LEGO has in particular exploited the 
opportunity side, but through changes in its relationships with partners such as Shell, as well as new collaborations with Non-Governmental Organizations (NGOs) like WWF, the company also addresses responsibility issues. For instance, LEGO works closely with its suppliers to try to reduce the shadow side of its supply chain.

\section{Better Dashboard, Better Management}

A key challenge in any organization is to monitor and manage performance. This involves developing useful performance indicators, which reflect the degree to which the company is attaining its goals. In addition, it requires systematic collection of data for these indicators and adjusting the course accordingly. This is a challenge that is difficult enough even when the company operates with only one performance dimension - the financial. Taking triple bottom line performance seriously, however, makes it significantly more difficult (see, e.g., Perrini and Tencati 2006; Schaltegger 2011).

Real performance management of social and environmental performance implies measuring and keeping track of the externalities that require monitoring and follow-up (Epstein and Roy 2001). A major challenge in this context is to develop appropriate indicators for social and environmental performance and to collect data related to them (Keeble et al. 2003; Gulbrandsen et al. 2015). In addition, it is difficult to compare across the three performance dimensions in order to steer the company's activities in a direction that takes into account all three dimensions and the relationship between them.

An important trend in companies' sustainability efforts is to put in place suitable key performance indicators-the so-called KPIs. These essential management tools can improve decision-making but are also important for external reporting purposes (Perrini and Tencati 2006). Increasingly, companies are reporting their social and environmental performance, either in sustainability reports or in the so-called integrated reports (Eccles and Krzus 2010; Etzion and Ferraro 2010). We are thus already moving toward a world in which investors and other stakeholders can rely on this type of non-financial information (see, e.g., Serafeim 2015). 
Measuring and managing social and environmental performance, however, require employees with the skills to identify existing KPIs or develop new KPIs that relate to these dimensions. There are a number of standardized measures of this kind, including the Global Reporting Initiative (GRI) framework or the FutureFit framework, but companies are increasingly also customizing measures and indicators used in combination with standardized indicators in order to manage particularly important aspects of their performance better. As negative social and environmental externalities will largely be unique to the individual company (or at least the industry), it will usually be convenient to use a combination of standardized measures that are relevant across companies (such as $\mathrm{CO}_{2}$ emissions and the like) and customized measures targeting the company's specific sunny and shadowy sides (Eccles et al. 2012).

\section{Walk It Like You Talk It}

A final feature of organizational design of importance in trying to become more sustainable is the incentives used to promote this behavior in the company. To succeed with this, the company can develop an incentive system that promotes sustainable behavior and disincentivizes socially and environmentally detrimental behaviors (Kiron et al. 2012; Eccles et al. 2014; Gulbrandsen et al. 2015). This is not limited only to financial incentives, such as salary, bonuses and so on. It may also involve organizational incentives, such as which behaviors the organizational culture stimulate; social incentives, such as social norms or various forms of pressure to conform; and moral incentives, such as shared beliefs about what is the right thing to do within the organization (Jørgensen and Pedersen 2011).

Any organizational member has limited time and resources and in prioritizing between many different tasks in their daily work, employees will emphasize tasks they perceive as most important. A major source of information for individuals about what is important and what to prioritize is whether there are positive or negative incentives tied to particular goal attainment or the lack thereof. This may involve specific financial 
bonuses tied to social or environmental goals. In organizational terms, it may involve promotions or other benefits for employees who perform especially well along these dimensions. For organizational and social incentives, it is particularly relevant how people talk of and see these types of objectives in the organization.

Using incentives to promote sustainability can be very powerful, and research shows that companies performing particularly well with regard to sustainability typically have corresponding financial incentives for managers who are responsible for such outcomes. However, this type of instrument should be used with caution in order to avoid crowding out employees' intrinsic motivation to achieve social and environmental goals. There is, however, reason to believe that tying incentives to non-financial performance can promote employee motivation for such goals since it can strengthen the employees' experience of contributing to something bigger than the company's profitability (Pedersen 2013).

The international aluminum giant Alcoa is a company that has received attention for its management control system for sustainability (see, e.g., Epstein and Buhovac 2014). This company was an early mover in identifying key KPIs, setting concrete goals, designing measurement systems, tying executive remuneration to sustainabilityrelated goal attainment and transparently reporting on its performance and the implication for executive pay. The company identified its key shadowy sides and set goals for improving each of them, which it in turn made public on the company website and in annual reports. Subsequently, the company measured these KPIs and tied a significant part of executives' performance-based pay to the attainment of the sustainability-related goals. The progress toward attaining those goals, and for which goals managers were more and less successful, is made public, and the company also reports on the concrete implications for performance-based payment. This allows stakeholders to monitor the company's self-reported goals, performance and progress, and thus stimulates the company to be more transparent while it incentivizes and commits managers to perform in accordance with the expectations such an approach creates. 


\section{Move the LEGO Blocks Around}

LEGO's new organizational design stems from a new goal and a new vision for the company. Both the owners and the management want to make the company sustainable. The company has put in place many measures already, and now it is being implemented with regard to the core product and the way it is produced. LEGO has assessed its own practices with regard to environmental sustainability, and the company understands that it must set new goals to align its own interests with planetary and societal boundaries. The company's organizational design is changed, a new department is created with a new manager who becomes part of executive management, employees are hired and the company engages with stakeholders inside and outside the organization, all of which is part of the efforts toward achieving LEGO's ambitious sustainability goals. In this way, LEGO builds an organization that is equipped to strive for social, environmental and financial objectives simultaneously, and thus it moves in the direction of aligning sustainability and profitability.

\section{References}

Aldrich, H., \& Herker, D. (1977). Boundary spanning roles and organization structure. Academy of Management Review, 2(2), 217-230.

Christensen, C. (2013). The innovator's dilemma: When new technologies cause great firms to fail. Cambridge, MA: Harvard Business Review Press.

Deci, E. L., \& Ryan, R. M. (2000). The "what" and "why" of goal pursuits: Human needs and the self-determination of behavior. Psychological Inquiry, 11(4), 227-268.

Du, S., Bhattacharya, C. B., \& Sen, S. (2010). Maximizing business returns to corporate social responsibility (CSR): The role of CSR communication. International Journal of Management Reviews, 12(1), 8-19.

Eccles, R. G., Ioannou, I., \& Serafeim, G. (2014). The impact of corporate sustainability on organizational processes and performance. Management Science, 60(11), 2835-2857.

Eccles, R. G., \& Krzus, M. P. (2010). One report: Integrated reporting for a sustainable strategy. Hoboken, NJ: John Wiley \& Sons. 
Eccles, R. G., Krzus, M. P., Rogers, J., \& Serafeim, G. (2012). The need for sector-specific materiality and sustainability reporting standards. Journal of Applied Corporate Finance, 24(2), 65-71.

Elkington, J. (1997). Cannibals with forks. The triple bottom line of 21st century. Oxford: Capstone.

Epstein, M. J., \& Buhovac, A. R. (2014). Making sustainability work: Best practices in managing and measuring corporate social, environmental, and economic impacts. San Francisco, CA: Berrett-Koehler Publishers.

Epstein, M. J., \& Roy, M. J. (2001). Sustainability in action: Identifying and measuring the key performance drivers. Long Range Planning, 34(5), 585-604.

Etzion, D., \& Ferraro, F. (2010). The role of analogy in the institutionalization of sustainability reporting. Organization Science, 21(5), 1092-1107.

Foss, N. J., Pedersen, T., Pyndt, J., \& Schultz, M. (2012). Innovating organization and management: New sources of competitive advantage. Cambridge: Cambridge University Press.

Gond, J. P., Grubnic, S., Herzig, C., \& Moon, J. (2012). Configuring management control systems: Theorizing the integration of strategy and sustainability. Management Accounting Research, 23(3), 205-223.

Gulbrandsen, E. A., Jørgensen, S., Kaarbøe, K., \& Pedersen, L. J. T. (2015). Developing management control systems for sustainable business models. Beta: Scandinavian Journal of Business Research, 29(1), 10-25.

Jørgensen, S., \& Pedersen, L. J. T. (2011). Organizing for responsibility. In O. Jakobsen \& L. J. T. Pedersen (Eds.), Responsibility, deep ecology \& the self: Festschrift in honor of Knut J. Ims. Oslo: Forlag1.

Keeble, J. J., Topiol, S., \& Berkeley, S. (2003). Using indicators to measure sustainability performance at a corporate and project level. Journal of Business Ethics, 44(2), 149-158.

Kiron, D., Kruschwitz, N., Haanaes, K., \& von Streng Velken, I. (2012). Sustainability nears a tipping point. MIT Sloan Management Review, 53(2), 69-74.

Pedersen, L. J. T. (2013). Systems of accountability and personal responsibility. In P. Gooderham, K. Kaarbøe, \& H. Nørreklit (Eds.), Managing in dynamic business environments: Between control and autonomy. Cheltenham, UK: Edward Elgar.

Perrini, F., \& Tencati, A. (2006). Sustainability and stakeholder management: The need for new corporate performance evaluation and reporting systems. Business Strategy and the Environment, 15(5), 296-308. 
Schaltegger, S. (2011). Sustainability as a driver for corporate economic success: Consequences for the development of sustainability management control. Society and Economy, 33(1), 15-28.

Serafeim, G. (2015). Integrated reporting and investor clientele. Journal of Applied Corporate Finance, 27(2), 34-51.

Seuring, S., \& Gold, S. (2013). Sustainability management beyond corporate boundaries: From stakeholders to performance. Journal of Cleaner Production, $56,1-6$.

Shamir, B., House, R. J., \& Arthur, M. B. (1993). The motivational effects of charismatic leadership: A self-concept based theory. Organization Science, 4(4), 577-594.

Strand, R. (2013). The chief officer of corporate social responsibility: A study of its presence in top management teams. Journal of Business Ethics, 112(4), 721-734.

Strand, R. (2014). Strategic leadership of corporate sustainability. Journal of Business Ethics, 123(4), 687-706.

Open Access This chapter is licensed under the terms of the Creative Commons Attribution-NonCommercial-NoDerivatives 4.0 International License (http:// creativecommons.org/licenses/by-nc-nd/4.0/), which permits any noncommercial use, sharing, distribution and reproduction in any medium or format, as long as you give appropriate credit to the original author(s) and the source, provide a link to the Creative Commons license and indicate if you modified the licensed material. You do not have permission under this license to share adapted material derived from this book or parts of it.

The images or other third party material in this chapter are included in the chapter's Creative Commons license, unless indicated otherwise in a credit line to the material. If material is not included in the chapter's Creative Commons license and your intended use is not permitted by statutory regulation or exceeds the permitted use, you will need to obtain permission directly from the copyright holder. 